\title{
THE INCANTATIONS OF TUBYAKU KOSTERKIN
}

\section{Aado Lintrop}

Tubyaku Kosterkin (1921-1989) was probably the last great Nganasan shaman. His father Dyukhade became well-known to the researchers of shamanism after the Russian ethnologist Andrei Popov had published his first book about Ngana-

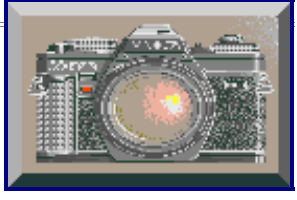
sans in 1936. Last chapters of this book ("Tavgitsy") contain rich data about Nganasan shamanism, obtained mostly from Dyukhade. The story about his initiatory visions and the description of his clean tent rite, lasting for seven days, have been quoted by many scholars (e.g. Eliade 1974: 38-42).

People said that before the birth of Tubyaku all of Dyukhade's sons had died in their babyhood. When his eldest wife was pregnant again (he had three wives), Dyukhade foretold that this time a boy would be born who would open the way for other sons. Tubyaku was born "in the shirt". He got his name from a button-like mole on his neck. The divination of Dyukhade turned out to be true after the birth of Tubyaku he had other sons indeed.

For many years Tubyaku lived in tundra as a hunter, fisherman, reindeer breeder, and a practising shaman. In the end of the 1940s, when the local Soviet authorities undertook the liquidation of shamanism in Taimyr, Tubyaku was imprisoned. He was indicted for shaman's practice not directly, but for accepting fees for his shamanist activities. After being released from prison in the 1950s he continued to shamanise.

Tubyaku's father was not the first shaman in the Kosterkin family. According to the legend told by Boris, the youngest son of Dyukhade, all shamans in their family stemmed from the ancient tribal shaman who, together with his children, survived from a great epidemic. The eldest son of this shaman had a daughter, Neiming. Neiming gave birth to a child - a snow-white boy with a long nose and big eyes. Neiming said, "I want to go away with my son and stand on my own feet. Let my son's name be Lambie (the Eagle). Let him also be called the Great and the Tall. His father was like a great eagle - the Eagle god." They began to live on their own. Lambie became a very powerful shaman. When he shamanised he turned totally invisible. (Simchenko 1968: 207-208.) Some people believe that the shaman gift of the Kosterkin family springs from Neiming (Gracheva 1981: 73-74, 1983: 134), but Boris said that the ancestor of Dyukhade was Neiming's younger cousin Syry'a (the White), also a great shaman (Simchenko 1968:210).

According to another legend told to A. Popov, there was a wolf-tailed shaman among Dyukhade's ancestors. "A wolf began to kill reindeer. Nobody could catch it. At last a shaman said: "I'll get hold of it. The wolf, like other animals, does also have its mother." He shamanised three days running, then said: "I put the wolf into my wife, you'll see what kind of child will be born." A wolf-tailed child - the grandfather of Dyukhade - was born. He became a great shaman and lived all his life with the tail." (Popov 1984: 109.) G. Gracheva introduced a different story about the tailed shaman. A childless woman asked help from a shaman who suggested that she should go to some distance from her tent in the winter night moonlight, and stand there facing the moon. When the woman did so, a wolf passed between her legs. The woman gave birth to a boy with the tail who got the name Taybula (the Tale) and became a famous shaman. (Gracheva 1979: 202.)

Dyukhade's daughter Nobopte (or Nobupti'e) was a powerful shaman, too. Her chief helping spirit was barusi - a mythical one-eyed, one-armed, one-legged creature (demonised dead). Whereas barusi has been considered an evil spirit, people seldom looked for Nobopte's aid. Some of them told 
that Nobopte had even got a child with barusi, but some believed that after marrying Nobopte his father put her barusi into one of his helping spirits. (Gracheva 1981: 74,76.) Tubyaku's brother Demnime (1926-1980) was also a shaman.

When Tubyaku was 7 or 8 years old, he had a dream in which he was guided by a girl to a woman whose face he could not see. The woman gave him his first helping spirit - a thin she-reindeer (Gracheva 1983: 136). Tubyaku's chief helping spirit was the eight-legged reindeer-stag Hotarie. When Hotarie appeared, summoned by the shaman, he often used other names according to the circumstances. For example, names like the Water-Stag, the Water-Eagle, the Nail of the Earth, the Private Enterpriser have been used (Kosterkina, Helimski 1994: 22). Tubyaku completed the set of his helping spirits by the clean tent rites. During these rites he got an iron reindeer from the Tenth god, a hornless reindeer from the Frosty god, a water-girl from the Mistress of water, seven sun girls from the Mistress of sun, seven women with dogs from the Smallpox god and an iron horse from the Westerly god (Gracheva 1983: 142, 144). The horse was called Mikulushka, it symbolised the Soviet power and had very special sphere of action - he supported only official business. The other names of Mikulushka have been the Shameless and All the Soviet Power. Tubyaku also had his special informers - three anthropomorphic Hositala spirits. One of them, Seimybtymy, had no eyes but could see everything. The second, Koubtumu, was without ears but heard all and the third, Nganabtumu, had no mouth but told the shaman about everything (Kosterkina, Helimski 1994: 22). Besides them, Tubyaku had more other helping spirits: an ermine, a mouse, a she-wolf with seven cubs, a seven-tailed dog, a polar bear, a brown bear etc. During the last years of his life, when he had neither the drum nor the shaman costume any more for the long journeys to the supernatural world, Tubyaku ceased to use the multitude of his helping spirits. He kept close relations only with Hotarie and Mikulushka the Iron Horse, even took them with him to Moscow and Novosibirsk. He said that travelling with them is not a big trouble, because one room could accommodate them all.

In 1989 Eugene Helimski from Moscow, Yuri Sheikin, and Olga Dobzhanskaya from Novosibirsk, Triino Ojamaa and Aado Lintrop from Tartu visited Tubyaku Kosterkin in Ust-Avam village. Among other materials, we recorded two short shaman séances. With the aid of Nadezhda Kosterkina, the daughter of Tubyaku, E. Helimski translated the texts of the séances and published them in Taimyrskij etnolingvisticheskij sbornik (Moscow 1994).

Background of the séances. Though the first séance was arranged at the request of the researchers, the leading motif was an incident that had taken place some days earlier, when Tubyaku's son-inlaw had popped a gun while drunk. It was a fluke that he did not hit anybody, but there was a serious reason for arresting him. The second séance was arranged a few days later at Tubyaku's will, because his son and daughter-in-law, who were absent from the first séance, had to leave the village for the seasonal work in a hunting team.

About the helping spirits. At the beginning of both séances Mikulushka the Iron Horse summoned by Tubyaku presented himself at first. During the first séance, when the shaman had to resolve some problems lying within the jurisdiction of judicial authority, Mikulushka made a longer speech. Among the rest he said (lines 22-31):

Let the son of yours sit here,

let him swear to the idols:

"Once more, such a deed I will not intend ever again," let him say.

"Let Hotarie take

my head as a pledge!

Do not let me slip into the dark house with bars. 


\title{
If I once more will do some bad deed, then I indeed will loose my head." \\ Let's now talk well. \\ Five suitable things for shamanising - I have them all. \\ Such as I am, my name is the Shameless.
}

The last lines can be interpreted so, that the shaman himself, while having five main helping spirits at his service, would be the person to whom one must tell everything without being ashamed. At the beginning of the second séance Mikulushka had even less to say. However, during the séance Tubyaku became convinced of the matter - the work in a hunting team - being adequately official, and Hotarie again gave the floor to the Iron Horse with the following words (lines 814-829):

\author{
All impure will be overcome by \\ Mikulushka the Iron Horse. \\ He is the lord of \\ thousands of stonemen, \\ of thousands of iron Russians, \\ of the birth of all machines, \\ of thousands of stone Russians. \\ He determines the going of thousands of iron Russians, \\ going of hefty machines. \\ He is enforcing the law. \\ These gods are working, \\ and with their working a strong law \\ is enforced like a stone, \\ is enforced like an iron \\ by the birth of the older god. \\ I'm gently going to lie down and rest.
}

From the last example one can deduce that for Tubyaku, Mikulushka the Iron Horse was like a spirit of the Soviet power and the shaman tried to act on it as he usually acted on some other supernatural being. At the beginning of the first séance (line 38) Milulushka declared: Such as I am, my name is All the Soviet Power. Of course, one can interpret the words so, that the shaman himself, while equipped with his five main helping spirits, had all the necessary power for resolving the problems lying within the jurisdiction of the authorities. At the end of the second séance (line 864) Mikulushka presented himself as the Grandfather.

During the séances besides Mikulushka the helping spirit Hotarie participated. He presented himself as the Water-Eagle, the Private Enterpriser, the Nail of the Earth, the Water-Stag, and the WaterBull. There are no direct descriptions of Hotarie in the texts. Only the lines 53-57:

My name is the Water-Eagle.

The inhabitants of seven countries living in the town draw the water from the summer place.

They are brought up with cold water -

my father and mother do it,

and the lines 683-685:

the day, shrouded from me

will be opened by Hotarie the Water-Stag,

the master of the water way, 
refer to a special relationship between Hotarie and water. According to A. Popov, the main helping spirit of Tubyaku's father Dyukhade was Huottarie - the Diver (Popov 1936: 85). But G. Gracheva wrote that Hottare - the Plunging One - was the name of Dyukhade's shaman ancestor (Gracheva 1983: 134).

According to the lines 478, 479:

three Hositala-gods, do come here closer!

and the lines 359-361:

\section{Tell all bad reasons to your father. \\ His ear heard, \\ Koubtumu-god is like the radio,}

one will assume that the other three helping spirits from the five suitable things for shamanising were three Hositala old men.

The structure of the séances was simple. In the course of preparations the tin-covered chest with the images of polar and brown bears on its sides was brought in. In the chest Tubyaku held his few remaining shaman attributes and idols. All necessary idols were put on the table and treated to drinks - they were sprinkled with alcohol. Tubyaku put on his shaman headgear and overall, the last was made for him by a Dolgan. Before the second séance he made a long address to the idols. Then all participants began to call the helping spirits, shouting houk, houk; and tuobtusi - the persons knowing well the shamanic tradition, helpers of a Nganasan shaman, they have to repeat each line of the songs-incantations - took up the melody of Mikulushka the Iron Horse and sang it without words. (1) Tubyaku swayed the shaman crosier with a bell on its top. His eyes were closed by the fringe of his headgear. (2) At the beginning of the first séance Tubyaku said that there was 'too little noise'. Then all participants made efforts to shout louder. The shaman was not content with the voices, for during the second séance he reproached his son who was absent from the first séance (lines 353-357):

\section{You did know about the children who were about to travel here, where did you disappear? \\ Tell your reasons! \\ The resounded noise \\ made by your elder brother and sister (3) \\ was not sufficient for the gods.}

Tubyaku has told Galina Gracheva about the role of an audience, that during the great séances all participants repeated the words sung by the shaman. "The more participants are present on a shaman séance, the easier for the shaman to go." (Gracheva 1983:140.) The voices of participants help the shaman and the helping spirits to travel in the supernatural world. On the other hand, it was believed that together with the shaman's soul and helping spirits the souls of all participants took a trip to the world of spirits (e.g. Popov 1936: 76).

About the incantations. When the shaman felt the spirit's arrival, he began to sing on its melody. The song consisted of fragments with different length (from a couple to several hundreds of lines), each starting with the words tamany, tamany - a sign that the shaman, who between the fragments spoke his own words for commenting the songs, would start to perform the speech of his helping spirit again. Tuobtusi repeated each line of the song. Nobody could speak with the spirits on his own initiative, but had to wait till the spirit asked him a question. After that, the shaman stopped singing and - if necessary - explained the question. If the person whom the question was addressed 
to did not understand, or his answer did not satisfy the shaman/the helping spirit, the shaman began a new song fragment, in which he tried to phrase it in other words. In some cases he added a slighting remark about the addressees wit, e.g. the lines 390-394 towards his daughter-in-law:

Tamany, tamany!

Her simple mind does not understand:

when you came to this house of yours,

a baffling word

from somebody you heard.

In the opening fragment of the first séance the Iron Horse greeted his old acquaintances and reminded them of the work they had done together (lines 1-16):

Tamany, tamany!

My name is the Iron Horse

who appeared in times of the Soviet power.

I can see everybody of you,

while you are preparing for the rite.

In Moscow times

it was I who did the work.

Yura, my son, on this land

have you brought your eyes.

Genya, my son, on this land

have you brought your face.

The rest of you I do not know, in Moscow times I did not see them.

Let's greet each other well!

They are saying that this land of mine is called Hotarie.

Then Mikulushka asked permission to handle the family problems (lines 33-36):

what should I do?

All my work is disturbed at present.

Let's suppose you say, "Do your own work."

If so, all my things will be in order.

During the following conversation Tubyaku's daughter asked the Iron Horse to arrange everything, so that her husband would not be imprisoned.

In the opening fragment of the second séance Mikulushka merely stated that those who brought in the idols had done the right thing. As the next part concerned only the family problems, the Iron Horse gave the floor to Hotarie with the following words (lines 341-348):

The trustworthiest among the five suitable for shamanising -

is it not Hotarie the Water-Eagle?

Now he has a good mind to talk.

Like these children, I shall only be the writer.

If I shall manage to write,

you will also manage well your winter road, your summer road.

The Water-Eagle, my master,

my food at summer evenings and mornings. (4)

Tamany, tamany! The speaking of Hotarie will be heard. 
The shaman compared himself with the visitors - like the researchers, he only registered the speech of the spirits. One can find some other lines diminishing the role of the shaman: my garrulous shamanising (154), I am not chattering without recognising all deeds and troubles (373), as my shamanising is properly chattering $(619,620)$.

The long fragments (119 lines at the first and 231 lines at the second séances) are distinctively monologuous, containing the lines referring to the inner reasoning of the shaman/helping spirit: at the beginning I thought to say, after that I thought to say, then I thought to say, thereafter I thought to say, on that day I thought to say, shortly I thought to say. The short fragments are dialogical, containing a guesswork about some matter related with an addressee and a prediction - what will happen, if the shaman is right. For example, the lines of the second séance 365-370, addressed to the son:

\author{
Tamany, tamany! \\ Now your way, \\ they say, is called the changed one. \\ How did you change your way? \\ If my guess is right, your two little bows (= sons) \\ will live without distress until they reach maturity.
}

Often the dialogical fragment divides into two parts - the first one makes a comment about the answer to the question asked in the previous fragment, the second one phrases a new question. For instance, the first four lines of the next fragment (371-378) express the shaman being pleased that his guesswork about the changed way of his son happened to be right:

\title{
Tamany, tamany!
}

May it not be your habit to suffer.

I am not chattering without recognising all deeds and troubles.

Your mind does tell to you: "The shamanising of my grandfather is right."

In the land where you were going to, when you had got there, from whom did you hear the word of returning?

If it is so

you will know what kind of work Kataraku, your son will do. (5)

On the base of published materials I may confirm that these sorts of guessing or divination were common to all Nganasan shaman séances. At the beginning of a rite, the so-called quest for the right path had to convince a shaman and an audience that the shaman, together with his helping spirits, is moving towards the purpose of the séance by the right way, all of them powerful for acting. One must not lie to the shaman, nor endorse a wrong guesswork of the shaman. (6) According to the belief, giving the false information amounts to misleading the shaman. The latter could be fatal to the shaman and his community (e.g. the story about the shaman who listened to the bad advice of an onlooker and caused the smallpox epidemic to kill himself and most of his community-members Popov 1936: 104-105). At the end of a successful rite, the shaman customarily foretold the future at the request of a participant. The divination, which did not differ formally from seeking the right path, may have been accompanied with casting lots by means of a drumstick.

In addition to the function of foretelling, the short/dialogical fragments are kind of magic - each of them is an attempt to act on the life of an addressee. From the viewpoint of the shaman the principle of such magic will be as following: if my words happen to be right, then you are going to be strong. 
The long fragments are more poetic and, therefore, less understandable than short ones. The shaman does not address them directly to anybody, though he may say the names of participants or relatives. At the first séance the words - at the beginning I thought to say - are followed by the characterisation of the situation (lines 65-75):

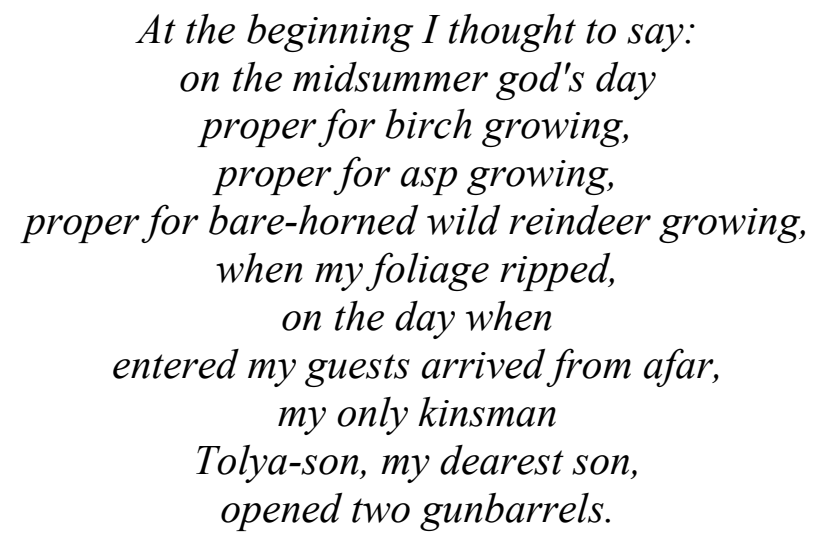

At the second séance after the words - at the beginning I thought to say - the shaman also determined the present moment. He spoke about the summer ending and the autumn beginning, and mentioned the present month (August) as the month of his trip to Moscow (Tubyaku visited Moscow in 1988). After that, the shaman dealt mainly with the welfare of his relatives during both rites. There are two kinds of magic in the long song fragments: undesirable events are excluded by means of the word, and uncertain or provisional things are associated with steady and constant ones, e.g. the lines 93-109 of the first séance:

when the warm day is over,

on the showery god's day,

when the end of the reindeer horns time,

end of the time of the horns of the bare-horned reindeer's father

is so close.

On that day, my guests,

while using the door for safely leaving the mother's womb, while using this opening of the Jovial god like the door,

past by the bad years,

as the inhabitants of two tents,

let the children brought up by me

settle on this riverbank

without suffering and crying.

Now the warm day flashed by.

Before this very same time will return again

in the year 1990,

let me not have losses.

Or the lines 559-568 of the second séance:

$$
\begin{gathered}
\text { After that, } \\
\text { the Mother of geese, } \\
\text { till yesterday having been hunted } \\
\text { by my two puny children! (7) } \\
\text { When approaches the time } \\
\text { of your going to your living mother, }
\end{gathered}
$$




$$
\begin{aligned}
& \text { on that day I thought to say: } \\
& \text { the bird's way of returning, } \\
& \text { the bird's way of leaving behind the sea; } \\
& \text { if I am leaning on these two ways, } \\
& \text { I find the support for my legs. }
\end{aligned}
$$

And the lines 632-638:

$$
\begin{gathered}
\text { Briefly, I thought to say: } \\
\text { if I can rely safely on the } \\
\text { appearing of botfly maggots, } \\
\text { the appearing of fly maggots, } \\
\text { the appearing of gnat maggots } \\
\text { brought up by sunbeam, } \\
\text { then let my ready-to-blunder head } \\
\text { find the support for it's legs. }
\end{gathered}
$$

The long song fragments consist mostly of the magic standards connected with the things the shaman had to act on. For example - as one can conclude on the basis of the published text - Tubyaku was of the opinion that his visitors coming from a distance were especially lucky people. He tried to transfer some of the presumable luckiness to himself and his children and grandchildren. The lines 648-652 put it very expressively:

$$
\begin{gathered}
\text { If the lived lives } \\
\text { of my guests today } \\
\text { - my dearest children with good luck- } \\
\text { will be used like a stand, } \\
\text { then today's ready-to-blunder, } \\
\text { my ready-to-blunder head... }
\end{gathered}
$$

In the long fragment of the second séance the shaman appeals to some supernatural beings for help or support, e.g. the lines 498-500:

while aiming at this day,

the moon provided with ears and eyes,

look back indeed!

and the lines 514-517:

may the moon, who is listening to the repeated incantation,

the moon with ears,

the moon with eyes, help me.

Also the lines 575-579:

$$
\begin{aligned}
& \text { today my stubborn, } \\
& \text { stubborn head } \\
& \text { is put to defend }
\end{aligned}
$$

the Mother of strong wild reindeer,

the Father of strong wild reindeer 
or the lines 625-627:

you, the god who commands the day,

if I indeed have ever spent my nights

together with the sun who spins round today

or 663-664:

$$
\begin{gathered}
\text { the Mother of bears, the Father of bears, } \\
\text { isten to me today! }
\end{gathered}
$$

All Tubyaku's references to the Soviet power, communist party and Lenin may actually be classified under the last category, because the shaman regarded the founder of the Soviet regime and the central authorities as supernatural beings and symbols of steadiness and stability. He even used the possessive suffix of the first person, while speaking about the Soviet power (lines 124-129):

$$
\begin{aligned}
& \text { My Soviet power in effect } \\
& \text { has set Gorbachov } \\
& \text { as the ruling person. } \\
& \text { Inhabitants of the country, } \\
& \text { spread by Lenin, } \\
& \text { have grown to the height } \\
& \text { of Lenin's head... }
\end{aligned}
$$

With the next fragment (lines 597-610 of the second séance) Tubyaku tried to protect the Soviet power from possible danger:

$$
\begin{gathered}
\text { For my visitors' sake, } \\
\text { for my present visitors' sake, } \\
\text { let my livingplace, } \\
\text { turned almost topsy-turvy, } \\
\text { become straight again. } \\
\text { The name of Lenin's party, } \\
\text { living today } \\
\text { and established by Lenin, } \\
\text { Lenin's komsomol, } \\
\text { the ruling of the Soviet power. }
\end{gathered}
$$

Do not let any ill-disposed person to gnaw at the strong law,

the fathers' law,

the mothers' law

established by Lenin.

At the end of both séances Tubyaku said, that if his words had been right, special visible signs would appear in the sky (e.g. the lines 331-333):

$$
\text { If I am really right }
$$

then in the direction of sunrise,

they say, the god's pattern will become completely visible.

The long fragment of the second séance also ends with a similar announcement. Besides that, the shaman connects the welfare of all participants with the rightness of his divination (the lines 709716):

But today, my dearest children,

if I am really right, 


\author{
then in the direction of sunset you can, \\ they are saying, there you can \\ see a visible dark cloud. \\ If you will see such a thing, \\ then, using my firm figure who spoke today \\ as a support, you will live past the bad years without suffering.
}

From the last three lines one can get the point of the séance - to give assurance to all participants. If signs are supporting the words of the shaman, then one may trust in the shaman and in his helping spirits. One may be convinced that the shaman is able to act effectively on behalf of every community member under all circumstances. Tubyaku said explicitly that a trustworthy shaman is the one supporting everybody who will remember him. He was well aware of his mission, but he also knew that after his death the times of great Nganasan shamans would be over. During the first séance he said (lines 282-285):

On the rapidly ending day of shamanism and idols a child will not achieve the trance instead of me.

All my helping spirits I shall bundle together, there will remain only the Soviet law.

\title{
References:
}

Eliade, M 1974. Shamanism. Archaic Techniques of Ecstasy. Princeton.

Gracheva, G. N. 1979. K knige D. K. Zelenina "Kul't ongonov v Sibiri". Problemy Slavjanskoj etnografii, pp. 193-204. Leningrad.

Gracheva, G. N. 1981. Shamany u nganasan. Problemy istorii obshchestvennogo soznania aborigenov Sibiri, pp. 69- 89. Leningrad.

Gracheva, G. N. 1983. Tradicionnoe mirovozzrenie ohotnikov Taimyra. Leningrad. Kosterkina N., Helimski E. 1994. Malye kamlanija bol'shogo shamana. Taimyrskij etnolingvisticheskij sbornik, pp. 17-29. Moscow. Lintrop, A. 1995. Shamaaniraamat. Tartu. Popov, A. A. 1936. Tavgitsy. Trudy Instituta antropologii i etnografii, tom I, vypusk 5. MoscowLeningrad.

Popov, A. A. 1984. Nganasany. Social'noe ustroistvo i verovania. Leningrad.

Simchenko, J. B. 1968. Nekotorye dannye o drevnem etnicheskom substrate v sostave narodov Severnoi Evrazii. Problemy antropologii i istoricheskoj etnografii Azii, pp. 194-213. Moscow.

All incantation texts are translated from Taimyrskij etnolingvisticheskij sbornik. Mosow 1994, pp. 30-106. 


\section{Comments}

1 Each helping spirit of a Nganasan shaman had the melody of his own. So the people knowing the tradition well could decide on the basis of the melody, which helping spirit was actually acting.

2 In my book about Siberian shamanism (Lintrop 1995:121) I have highlighted the importance of the restriction of visual sensations as a part of the technique of ecstasy. Most shaman headgears in Siberia had a fringe, special ties for blindfolding were also used, often a séance took place in the dimness etc.

3 Here the words 'elder brother and sister' are used for Boriss Kosterkin and his wife.

4 By the food of spirits is meant alcohol.

5 i.e. Labtimaku will live at least till Kataraku will reach the working age.

6 During the séances, Tubyaku and his helpers told the visitors repeatedly that one must give only truthful answer to a shaman.

7 Tubyaku's son and daughter-in-law had returned from the geese hunt two days earlier. 